\title{
WUDA GEOINFORMATICS CO., LTD. (GEOSTAR) (BRONZE SPONSOR)
}

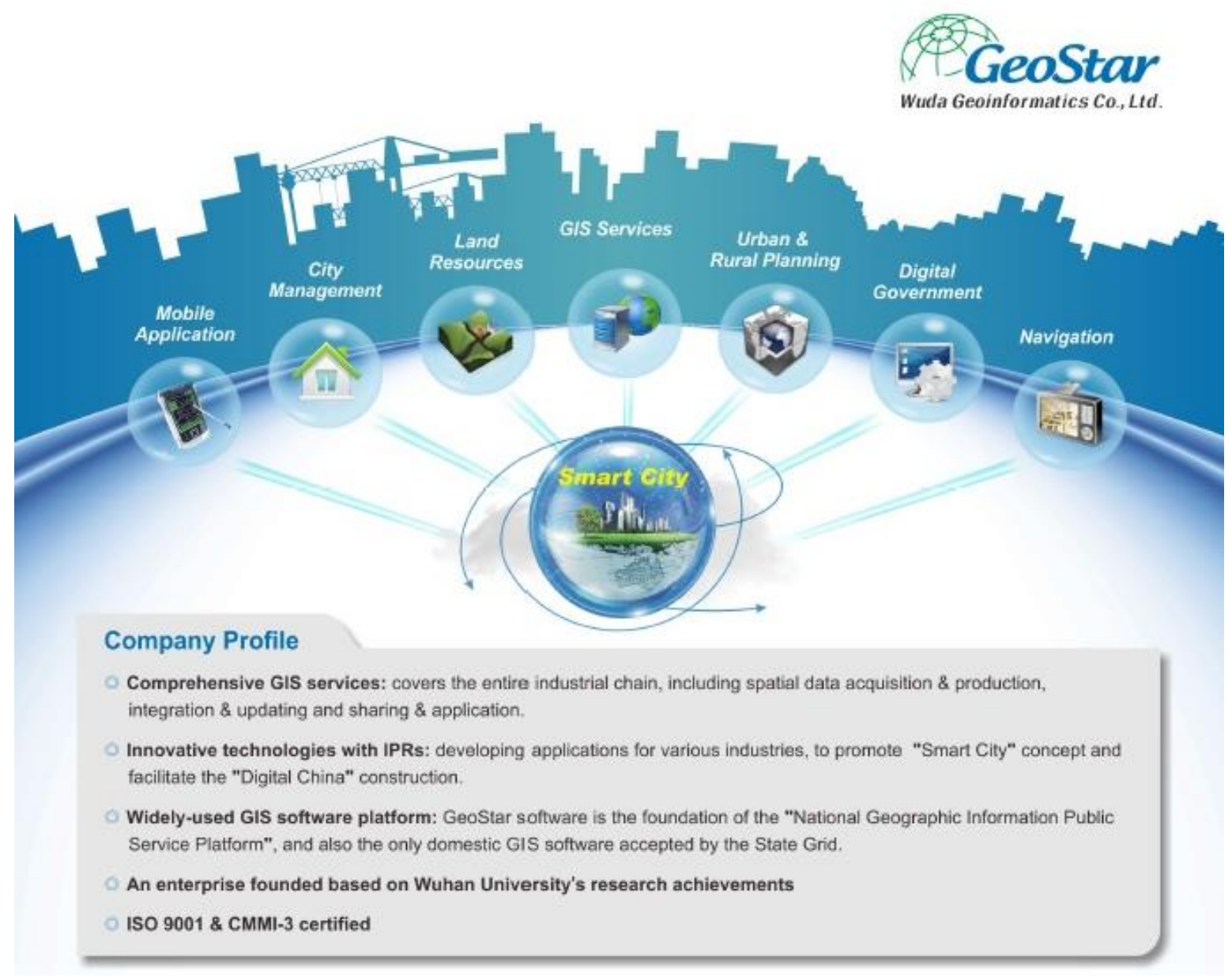

